Portland State University

PDXScholar

6-30-1971

\title{
The Effects of Marihuana Extract Distillate on Eating Behavior of Rats
}

Terrie Wetle

Portland State University

Follow this and additional works at: https://pdxscholar.library.pdx.edu/open_access_etds

Part of the Psychology Commons

Let us know how access to this document benefits you.

\section{Recommended Citation}

Wetle, Terrie, "The Effects of Marihuana Extract Distillate on Eating Behavior of Rats" (1971). Dissertations and Theses. Paper 1520.

https://doi.org/10.15760/etd.1519

This Thesis is brought to you for free and open access. It has been accepted for inclusion in Dissertations and Theses by an authorized administrator of PDXScholar. Please contact us if we can make this document more accessible: pdxscholar@pdx.edu. 
A ABstract OF THE THESIS of Tarrle Wetle for the Mater of science

In Peychology presented Jume $30,1971$.

Ttle: The Effecte of Marthuma Extract Distilate on

Eating Bahevior of Rate.

APPROVED BT MAMERS OF THE TERSIS COMITTEE:

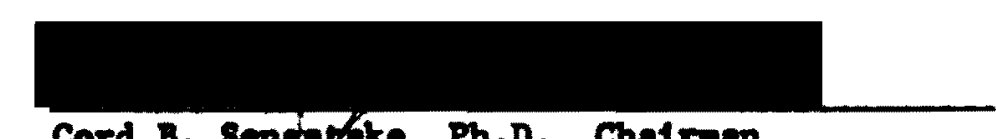

Cord B. 8engebtike, Ph.D., Chatrman

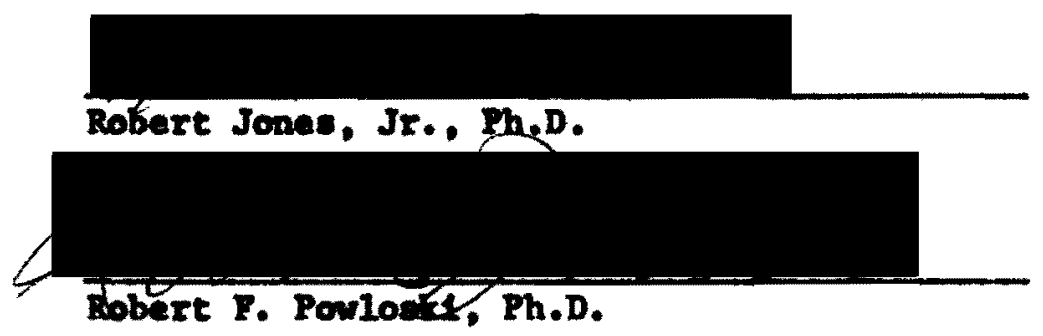

Since hunger drive is often used as a notivating factor in aninal learning experimentation, it wes decided to determine the effects of warlhuina extract diatillate on the enting behovior of rate. Carlini and Xraver (1965) found anthume extract injections to have a facllitory affect upon ane performance. They ouggested that facilitation could hrve meulted from an incranes in hunger drive. However, If the dosage level 1s high, this effect way last for a short tine and be followed by a disinterest in food. Scheckel et al. (1968) report that sowe monkeye. at wry high dosage levels of tetrahydrocannabinol etarved to death in post-drug depreseions. Human atudies Indicate sone increased hunger or 
"taste enhmeenent" (Grinopoon, 1968; Holl1ster, et a1., 1968; Anes, 1958 ).

Se were 20 anle and 20 fenale edult Sprague-Daviey albino rate. antintalned in how cages wth ad-11b food and water. Ench enimal wa asalgmed to one of five groups so that exch group contained four andes and four fomales. Bnch group recelved one dosage level of the drug throughout the entire expariwent. Three dosage levels and two controls were uned. Food deprivation levele of ad-11b, 12, 24, and 48 hours were aselgned sccording to a balanced Latin equare dostgn. The drug, anrihuana axtrect diat1linte, wa adnintetered through in Intraesophogeal tube and hypodertede artinge. The study was divided into two parte, each of four wak' duration. In the f1ret, after edaindetration of the drug, the aninale Immediately were placed into a cage wth a known anount of food present. The food wes waghed after three and 24 houre to deternine the mount of food eaten. The second expertmant of the study repace all procedures exeept animals were not given food unt11 thour after the drug was ablnistersd.

Resulte show an inverae relationohip between dosage level of anthuna extract distillate and amount of food eaten. Bffecte of doeage level, hours of deprivation, sex, Iatency of lood presentatica, and the poselbility of tolarance or Increased seneltivity to the drug are discused. 
THE EFTBCTS OF MARIHUAM EXTRACT DISTHLLATE

ON BATING BEHAVIOR OF RATS

by

TERRIE WETLE

A thesis subeltted in partial fulfillmat of the

requiremonte for the degree of

MASTER OF SCIENCE

In

PSYCHOLOGY

Portland State University

1971 
TO THE OFFICE OF GRADUATE STUDIES:

The members of the Comittee approve the thesis

of Terrie Wetle presented June 30, 1971.

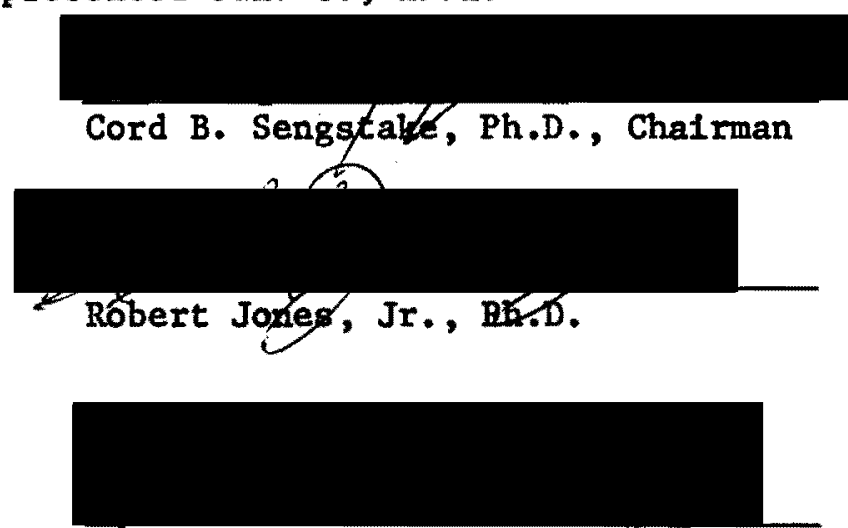

Robert F. Powloski, Ph.D.

APPROVED :

Robert E. Jofes, Head, Department of Psychology

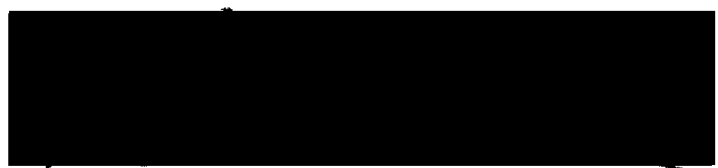

David T. Clark, Dean of Graduate Studies

June 30,1971 
ACKNOFLEDGMENT

To a time of valting I allude

When $I$ offer gratitude,

A year's gestation this did take,

guided by Cord B. Sengstake.

The help from him in kind and size

I could never uintintre.

I also thenk and w11 ne're forget

The Jones-Powlosk1 Duet. 
TABLS OF CONTBNTS

PAGE

ACKROMLEDGMENTS .....................

111

LIST OF TABLES

CHAPTBR

I REVIEN OF LITERATURE. . . . . . . . . . . . . 1

Subjective Reports - Mood ......... 5

Subjective Reports - Perceptual ...... 10

Phyelological Changes.......... 15

Performance Tosts - Muman . . . . . . 19

Animal studies. ............. 20

II METHOD. ..................... 27

III RBSULTS .................. 30

Cagual Observations ........... 34

IV DIscussion ................... 35

v conclustons ................... 39

VI REFRRERCES ..................... 40 


\section{LIST OF TABLRS}

TALE

PAGE

I Subjective Raports - Mood Changes . . . . . . 6

II Subjective Reports - Perceptual Changes . . . . 11

III Physelological Changes - Humen . . . . . . . . 16

IV Behavioral and Physiological Changes - Antmal . . 21

V F Values for Analyeis of Vartance . . . . . . 30

VI Keman-Koula Results ............... 32 
Cannable aetiva 1s Indeed a ublquitous plent, both geographically and historically. The earliest record of use of the drug is found in a Chinese compendium of nediclnes, the herbal of Experor Shen Viung, dated 2737 B.C. (Grinopoon, 1969). Its ues an en Intoxtcent epread from China to Indla, then to North Africa and from there to Europa in about 1800 A.D. Between 1840 and 1900 wore then ow hundred nodteal articlea were wrtten recomending it for vartous aflente (Ams, 1958).

In the Wetern Honiophere, marthuena had been knowa for centurtas In south and Central smertea, but was not used in the 0 . 8 . as a therapautic unt1 the 19th century and a an Intoxicant in the $1920^{\prime}$ (Grinopoon, 1969; We11 et al., 1968).

The wadical use of Conneb1s eative was particularis prominent in India; howerer, In the 19th entury, the drug wa wdely preacribed In the Wetern vorld for allments wch w coughing, fat1gue, thevmatim, estha, delirium tremens, atgrain headache and pafnful manotruation. However, Ita we declined aciswhet wth the introduction of arathetic hypnot1ce and enalgétes, and 1te final demise as a wedteal alde was brought about by the Tax Act of 1937 (Grinmpoon, 1969). Faderal control of anthuana is presenty the reeponelbility of the Federal Duraeu of Narcoties under the Marthuma Tax set of 1937 (U. S. Code Ttele 26 , Sectione 4, 741-4, 776). The act requires all persons with legitinate noed to handle arthuan to regleter and pey an oceupational tax, 
requires that all marthuana transactions be recorded on official forms provided for that purpose, makes transfers to a registered person subject to a tax of $\$ 1$ per ounce and makes transfers to an unregistered person subject to a prohtbitive tax of $\$ 100$ per ounce.

Marthuana, or hemp is an herbaceous annual growing three to eIghteen feet in height depending on 8011 and climate, wth male and female flowers growing on separate plants. When the female plant is about to flower, the tops become covered wth a multitude of plur1cellular glandulose hatrs. The tops are very etlcky, and a resin often spreads to the surface of the leaves or branches. This reatn appears to contain most of the intodeating principle of the plant. In the Far East, this reain, charas, is drled, then pressed to produce a greentahblack mass which is then smoked with tobacco. Genja is a sintlar resinous nass wich is also amoked wth tobacco. Bhang 18 a tea-11ke beverage or candy produced from the resinous upper leaves of the female plant (Adams, 1940; Ames, 1958). In the U. S. and several other countrles, the cops of the flowering plante are cut and drted, the coarse waterial removed and the remalning leaves chopped to be smoked in elther a clgarette or pipe. Charas is the highest grade of Cennabis and 18 also properly called Bnghish, though this nawe in comon usage includes sow Infertor grades (GrInspoon, 1969).

The use of Cannabls eativa as an Intoxicant has taken many forrs. The Hindus, In early tines, regarded it as a holy plent, belleving that the gods extracted nectar from 1t. Much of the eanctity was due to the 
belief that the drug "claared the head and stimulated the braln to think." Som Mohamedan sects regarded the plant as an embodiwont of the spirit of the prophet Khizar Elifah. The lives of some tribed in the Congo center around hemp, and it is anoked ragularly. The man who countts a misdeed 18 condenned to smoke until he loses consclousness. In South Africa, some women smoke in order to stupefy themselves during childbirth, and later the chlldren are given a mash of ground up bread and marthuana when they are weaned. It 18 also recowanded in this area as a local application for snake bite and cancer, sintlarly for malar1a, anthrax and dysentery (Amas, 1958).

As Interesting as these reports night be, wore Information regarding the effects of the drug may be galned from reviewing sclentiflc 11tarature. First, the oubjective effects as reported by human subjects will be discussed in relation to both mood and perceptual changes, next the phyalologtcal changes are consldered, followed by performance tast results and finally a review of the studies done with animals.

It 18 important to note that there are many contradictions concerning the effects of the drug. often these can be attributed to differences in dosage levels, route of administration, fors of cannabis used, poor experimental design or b1ss of the experimenter. Bspecially In the early studies, the experimenters seewed hard pressed to "prove" that the use of Cannabis was followed wthout exception by a paychosis, leading to Increased sexuallty, Increased criminality and total lack of ambition, and was in nost cases a major cause of addiction to heroln 
(Abeleca, 1968; Amartean Hedical Asscclation, 1967; Ares, 1968; Charen et al., 1946; Gank111, 1945; Kaelex, 1967; Keoler, 1968; Nabb1tt, 1939; s1ler et al., 1933; Somnenrelch et al, 1962; Ty1den, 1967; Wolff, 1948 ). In other atudies, phyelenl ayptoma are complicated by the transport nadia for the drug alnce Marthuana is often adminisered with other preaunably Inactive substances. Anes (1958) reports that severe abdominal cramps and diarxhea were direct symptom, though he later adulte that these "way be accounted for In pare by the large mount of Ilquortee contalned In the 48 p111s given the subject." Mny of the etudles discused below ouffer from poor design and are included for their historfeal intereat rathar tha sclentifle algniflemee. In revieulng the following atudies a need for wa11-deetgned beate research in anthuene effects becowas appexant.

In the $1940^{\prime}$ ' 1t was deternined that the active conotituents of marthuana were vartous iscarers of tatrahydrocannablool (GrInspoon, 1969). Recont stud1es have determined that 9 tetrahydrocannabinol and 8 cetrahydrocannabinol are found in marthuma (Hollleter at al., 1968; Lermer, 1963) and hove warthuena-11ke effecte In wan (Iabe11, 1967 ). 9 -tetrahydrocannabinol, both as a natural extract and aynthetically produced, has been weed In various human and animal studias. Other datnistration forms are swoking. Ingeeting natural arthuna and vartoue extracte. V1er1a et a1. (1967) report that onoking Induces more Intenne Intoxdcation than eating or chewing the drug. However, the oyptose are sintlar if dosage level of Ingention is Increased. Unt11 recently, the 
wost cownon forw of etandardialng the potency of the drus was through the abolition of the corneal reflex of rabblts. A poattive ases is the anoumt of drug needed to abollsh 807 of the reoponces in a three-ulnute pertod of meavurwent (Salustiano ot al., 1966). For a nore complete description of this technique, see Valle et al. (1966). Potency has bean found to correlate clocely wth the amount of 9 cetrahydrocennabinol

In the smple (Bollister et al., 1968). In sore recent studies, dosage levele are given in terme of 9 tetrahyarocannabinol.

\section{Subjective Roporte - Mood}

A sumary of the studies utilising oubjective reports from human abjects is given In Table I. The oyptome described run the ganut frod pleseant or beneficial, through confusing and unpleasant to panic. Often many of thewe differant syptons are described by the sane cubjects at varlous Ievele of intoxicetion.

A typicel coures of Intoxtcation is given by Grinspoon (1969).

The Intoxication is Inttiated by a pariod of anxiety wthin 10 to 30 minutes after moking, In which the user develope feare of denth and anxiatios of a vague nature assoctated wth restessnese and hyperactivty. Wthin - fev alnutes he begina to feel wore caln and develope definite euphorta; he becomes talkntive. . Is elated, exhilarated. - .begins to hwe. - an sotounding fealing of 11ghtness of the 11mbs and body. . Iaughe uncontrollably and explosively. . .without, at times, the olightest provocation. - .has the Impreseston that his convereation 1s witey, brilliant. . The rapld flow of 1deas gives the Impresetion of brilliance of thought and obeervation but confunion appeare on trying to remember what was thought. . . he way see vieual halluclnations. . Fleshes of light or morphou form of Fivid color which evolve and develop 
1nto geometric f1gures, shapes, human faces and plctures of great complextty. . After a longer or shorter tina, lasting up to two hours, the smoker becomes drowsy and falls Into a dreanless sleep and awakens wth no physiologic after-effects and wth a clear menory of what happened during the intoxication.

\section{TABLE I}

SUBJECTIVE REPORTS - MOOD CHANGES

\begin{tabular}{|c|c|}
\hline Mood Change & Study in which it wes reported" \\
\hline Satiefying, pleasurable & 23,24 \\
\hline Laughter, happineas & $2,5,8,16,21,23,35$ \\
\hline Wtty, br1111ant & $2,8,21,23,24$ \\
\hline Euphoria, elation & $2,5,8,16,21,23,27,35,52$ \\
\hline Bxeltement, hyperactive & $2,8,16,35,41$ \\
\hline Talkat1ve & $2,8,21,35$ \\
\hline Lghtheaded, dizxy & $5,8,23,52$ \\
\hline Increased sexual1ty & No Increase 2 \\
\hline Increased objectivity & 21 \\
\hline Increased aggression & No Increase 23 \\
\hline Confusing, unpleasant & $2,8,23,24$ \\
\hline Anxtous, panic & $2,7,8,11,21,23,35$ \\
\hline Reare, paranola & $2,8,21,35$ \\
\hline sleepy, dreany & $2,5,7,8,20,21,23,35,41,52$ \\
\hline Relaxed, caln & $21,23,35$ \\
\hline Depreseed & 11,41 \\
\hline Stup1f1cation, unconsclous & 20,35 \\
\hline
\end{tabular}

- Indicates number of atudy in reference section. 
For the wost part, most of the aymptome in Table I need no explanation; however, there are a fow worth noting. The first of these 1. a report of increased sexuality. Anes (1958) descrtbes this a a "warm glowing" feeling in the area of the pelvis, and a lowering of Inhibiticas. One subject, aged 32 , who had smoked the drug for may years stated that "dagge (arthuena) mans wowen, wurder and f1ght." Ha clatwad that his sexunl vigor wes so anhaneed that he had slept with four or flve wonen In a eingle night. However, further investigation revealed that this particular oubject was definitely nentally disturbed before wing the drug, and his reports about the drug conflicted from Cae twe to the naxt.

Charen ot al. (1946) present reporte of Increased sexual1ty but attributes this to lowering of Inhibitions and positive group sanctions. Nasb1tt (1939) reported enhanced cexunl drfve but presents no aupporting ovldence. The Mayor'a Connttee on Marthuana (Allentuck, 1942) dented any Increase In saxual drive due to the drug. Sexual "exaltation" has been reported in only one enimal atudy (V1erla et al, 1961) but there only as a cagual observation. Mdans (1940) states that although the drug way lower inhibitions, it is definttely not an ephrodesiac.

The wost often mentioned syoptcon in all of the 11 terature, both popular and professional, 1s auphorla. "The aubject firet feels himself. . capable of extreordinary feate of prowes. . .he way suddenly be overcome by absurd and irrealetable laughter induced by my trifling incident wich is very often not wuelng even to the elightest 
degree" (Adums, 1940, p. 117). Howrver, experienced subjects are able to control this euphoria to a certain degree if en external task is presented (We11 et al., 1968). Often, this "vivld cense of happlnase" 1. not linked with any particular atimulus but rather juat a general sense of well being (Resbitt, 1939). It 1s at this stage of the Intoxdcation that the subject feele particularly brilliant and vitty and w11 often become very talkative. Ames (1958) quotes one eubject, "Thare is no wental or phyelcal feat of which I do not feel capable. I anjoying talking becausa co many different aesocietione occur to wa." p. 980. Another eubject reported that he vas acquiring deeper IneIght Into bastc personality structure and that he had a new ararenese of the nature of thinge. However, this "Increased ewareness" is not without 1te problems. To continue the quote,". .my talk 1s discomected caly bacause I imadiately forget previous statemants." p. 981. A almilar phenowene is reported by one of thal's at. (1968) aubjects, ". . there was a sense of the past dieappearing as happens when you're driving too long without eleeping. With a etart you wake up to realise you were aleap for an instant; you discover yourself drifing along the roed. It was the same tonight with eating a andulch. I'd look dow to discover I'd fust anallowed a bite but I hadn't noticed It at the time (p. 1240)." Th1s "performance wthout cuarenese" is raported by enother of Hall's subjects, "Tine eaced very drawn out. I would keep forgetting whe I was dolng, especially on the continuou parformence test, but sowhow every tiwe the ' $X$ ' (exiticel letter) cane up, I found myeelf 
pushing the button (p. 1240)."

There are conflicting reports as to whether this sense of prowese and capabillty lead to hyperactivity. All reports of hyperactivity are found in "lists" of symptoms, efther related by habitual usars or as "common knowledge." lot one atudy substantiated this clatm with empirical evidence. On the contrary, all reputable etudies report, 1netead, a very relaxed dreany state in which wany actions are "conaldered" but few undertaken. Well et al. (1968) reports that wile in this atate, subjects are able to perform adequately but would much prefer to simply "enfoy" the expertence. The sane argument holda for reports of Increased "aggresefon." Although this is a popular belief in the folklore of the drug, there is not a oingle well-dealgned study to support thin supposition. In contrast, sentos et al. (1966) in a vell-controlled study demonstrated that mar1huana decreased both agression and spontaneous motor behavior in mice. This hes aloo been demonstrated in primates (Scheckel et al, 1968).

Paranola, andety, fears or pantc are mother often reported ayuptom complex. The degree of this fear may be controlled by two factors. The first is dosage level. The wot severe fear reaction is roported by Ama (1958) only in patients recelving high dosage levele. One patient belleved that almple electrophyolological equipwent wth which he was falliar was really giving hid electroconvulaive shock therapy. The second factor as Adams (1940) auggeats, 1s that the subject way become extremely wore sensitive enotionally. A subject who normally 
dilikes comeone allghtly w11 have an intense hatrad under the influence of the drug. In thts sense, any vague fear w11 be magnifled into a panic. Therefore, the degree to whlch the situation 1s potentially frightful also be a factor.

This increaced fear is reported to alternate with a mood of extrame detachment. Anes (1958) eald that subjects could report very palnful or unusual eymptows wth a totally detached manner as if their body were not their own. Users often report a sensation as if they are wrely watehing a seene and that they are one of the actors. Scheckler (1968) reporte whet appears to be a similar resction in monkeys at higher dosage levels.

\section{Sublect1ve Reports - Rerceptual}

Perhaps the wost comon changes reported in the popular literature are those within the sence modalities. They are reported as "enhancenent" or "distortion" depending upon the philosophical bent of the researchar. Each sense modalfty will be discussed in turn, deccribing both subjective reports and emirical evidence. 
TABLE II

SUBJECTIVE REPORTS - PERCEPTUAL CHANGES

\begin{tabular}{|c|c|}
\hline Perceptual Change & study in which it was reported* \\
\hline Bear1ng "enhanced" & $3,7,8,21,23,27,35$ \\
\hline Auditory halluelnations & 27 \\
\hline Ballucinations; vielons & $2,7,8,21,23,27,35$ \\
\hline Viaual parception diotorted & $2,5,8,23,27,35$ \\
\hline Visual perception enhanced & $7,8,16,21,35$ \\
\hline Iime diatortion & $5,3,8,16,21,23,27,35,52$ \\
\hline Spatial d1atortion & $2,5,8,16,27,35$ \\
\hline Paln dininiohed & Increased 8 \\
\hline Warnth or cold in extrentties & $8,20,23,35$ \\
\hline Bxtromit1es, 11ght, floating & $8,21,35,27,35$ \\
\hline Taste enhenced & $8,21,35,51$ \\
\hline Hunger increaned & $5,8,21,35,35,52$ \\
\hline Thirat, dry wouth & $5,8,21,23,27$ Increased eal. 8 \\
\hline
\end{tabular}

Indicates number of etudy in reference section 
One of the earliest widespread uses of arihuma in the United states was by jaxz mustclans for the purpose of enhancing their masical ability. They reported "Increased sensitivity to sound and keenar appreciation of thyth and tining" (Aldrich, 1944). As 11lustrated in Table II, aubjects in mony studies report increasad hearing acuity. This has been varlously deacribed as "a lowertng of the censory threshold especlally. . . for acoustical stimul1," "sounde are clearer," or "hearing more acute" (Roll1eter et al., 1968; Nebltt, 1939). Auditory hallucinations have been reported (Keeler, 1967) wth no subetentiation. Aldrich (1944) attempted to determine the affecte of a "barthuma-11ke compound" on wastcal ab111t1as. The drug ueed was a pyra-hexyl compound, reported by exparienced users to be quite simliar to marthuana. Aldrich reports a general dacrease in abllity as measured by the Senshore Test (Seashore, 1938). Subjects reported that they felt they had improved when, In fact, they had not. It 1 s not within the scope of this paper to discuss the Iinteations of the Seashore Test; however, it is important to note that on sow scales of the test there was actual Improvement though it is difficult to Interpret Aldrich's results, because of abigulties in design. In addition, he presented netther Individual data nor statiotical teste for significance. It would suffice to say that impairment, if my, is alight, and the subject definttely reports an enhancement in the pense of haring.

There are, hovever, substentiated reporta of changes in vigual perception. Both enhancenent and hellucinations are reported, often by 
the same researcher. Ames (1958) quotes a nalve subject, describlag

his Elrat experience with the drug.

W1th we the flrst perceptual change was a change in the colour and outline of objecte. Colours becsure striking and vivid--the curtaing were a vidid green, the room looked frenhly palnted and the figures in the roon looked as If thay had been cut out of cardboard. Thare was no third dineneion. They were flat with bright colours and sharp outllnes, and were seen through a screen of moving dot: like a newaprint photograph, with noving dot: Intead of at111 ones (pp. 979).

These "halluclnations" appented wth the eyes open or closed and did not appear in all oubjects. "Hallucinations" are raported in a number of studies often without definition. Nllentuck et al. (1942) describe "pseudo-hallucinations" as "flaghes of 11ght and apparitions," Holl1ster et al. (1968) as "viatons on the celling" and flnally, Adase (1940) an an enactwent of their "wost Intimate and secret thoughts." Grinapoon (1969) cuphasizes a heightening of senoltivity to external atimulf, "reveallng datalls that would ordinarily be overlooked, nakes colors seem brighter and richer, brings out values in works of art that proviously hed 1ittle or no meaning to the viewer." Again, it is Important to note that these effects are somewhat dependent on dosage 1eve1. Those studles reporting the most dresuatic Flousl chenges were those using very high dosage levels. Other related changes are of some Interent. Ames (1958) reporte m Increase in both Intensity and duration of after-Images, though he does not describe this in detall.

Two distortions which appear to be quite Interrelated are those of 
parception of the and apace. Hall at al. (1968), In a carefully controlled study weing both natre and experienced subjects, denonetrated a change In judgant of time. Onder Influence of the drug, many subjecte doubled their Intelal (undrugged) astimate of a 5-ninute open. This owe observation of an Increase In "eubjective tim" is roported in a numbr of studies (See Table II). Another often reported syuptom is apatial distortion, were distances appear to be longer than they actually are. Ane (1958) IInke this to the temporal distortions in that cubjecte felt that a corridor was "ingensely 100g" because it took so long (eubjectivily) to be wheled dom $1 t$.

Data concerming the canse of touch are conflicting. Hesbitt (1939) roporte that the conse of pain is dimintehed but fives no evidence to apport this statemant. Anse (1958), ut111sing the subjective reports of nalve eubjecte, notes on Increase in the eansation of pain. One patient roported "agony" from a elmple Injection, further supporting "enhancenat" of cxternal etfmul1; however. Anes also polnte out a "curfous detachaent" a $1 f$ it wre someone alse's body thnt ves experiencing the pain. Thts "objectivity" Is described by a nuber of subjects in any atudies (Sea Tab1e II).

The final perceptual change to be discused is that of enhenced taste and ow 11. Anes (1958) gave the wost dranetc report of enhanced taste parception when one of his subjects reported that "even hoepltal food teetes good." subjecte who ware not hungry bafore would eat wth rallsh when food was presented. Grinepoon (1968) connacts the "tarte 
enhencesent" with Increased huger. "It generates a high appreciation of food, so that the pereon under the influence may approach an ordinary diab With the enticipation of a gourmet confronting a opecial treat." Hollioter et al. (1968) also reports 1ncreased hunger for subjects taking tetrahydrocannabinol.

\section{Phrelological Changes}

Reporte of Increased hunger lead to a number of 1ntereating phyelological stud1es using hesen subjects. The f1rat group of studiee concarns lteelf with the level of glucose in the blood, bypothealang that increased hunger 1s due to low levels of blood ougar. As can be ceen In Table III, three studtes report no change In blood sugar level. Bddy (1965) was the only researcher to report hypoglycaenia and gave no empirical eupport for the symtom. Naueea and vontelng are two other aymptons, poselbly related to hunger, that have been roported by a number of rasearchers. These syaptoms ara wore likely to occur if the uaer 1s anive rather then experlenced, or if the drug is ingeeted rather than Inhaled, or if the anount used 1s lerge rather than and1 (Ames, 1958; Gr1nopoon, 1969; Boll1nter et a1., 1968). 
TABLE III

PHYSTOLOGICAL ChaNGrS - hUMAN

\begin{tabular}{|c|c|}
\hline Phys10logical Change & Study in which it was reported." \\
\hline Hypoglycem1a & 16 \\
\hline Plasma glucose, no change & $8,23,51$ \\
\hline Nausea, vontting & $5,8,20,21,35$ \\
\hline Diarrhea & $5 *$ \\
\hline Duretic & $8,21,35$ \\
\hline Shaking, trembling & $8,20,21,23,35$ \\
\hline Muscular contractions & 8 \\
\hline Chest constrictions & 23,35 \\
\hline Shortneas of breath & 23 \\
\hline Pup1l dilation & 5,20 \\
\hline No pupt1 change & $21,23,26,52$ \\
\hline Heavy eyel1ds & 11,22 \\
\hline Conjunctive Injected & $5,8,23,26,27,52$ \\
\hline Headache & $2,8,20,23$ \\
\hline Electroencephlograph change & 8 \\
\hline Ataxia & $5,7,20,21,23,52$ \\
\hline
\end{tabular}

*Indicates number of study in reference section

t* Sce explanation in text 
Dlarrhea was reported to be caued by marihuana by one researcher (Ame, 1958). However, se prevlously mentioned this subject was given 48 grains of marthuana, each grain encepeulated in 11quorice. Even Nes wes forced to admit that the symptoms "may be sccounted for in part by the laxge enount of 11quortce contatned In the 48 p1lls." Several studles have Indicated that the drug acte as a duretic, Increasing urination in both frequency and wount (See rable III). Increased ealivation has also been notad by some (hmes, 1958).

Another group of syaptons include muscular contractions, constrictioas of the chest, shaking, trembling end ataxda. Ae can be eaen In rable III those wot often 11sted are shak1ng and/or trembling. Th1s is usually a rosult of high doses (Awes, 1958; Grinnpoon, 1969). Holl1ster et al. (1968) roporta weaknese as dewonstrated with the f1nger ergograph. Hollieter stresses the fact that eny tremor, if present at all, is very weak, much weaker than that produced by othere of the paychosctive drugs. Ataxia, perhaps related to diszinese, is a commily roported syaptom and may be also listed as poor coordination. Muscular contractions were reported by Ames (1958) at high dosage levels. Constrictions or "tightnass in the chest" ware also listed so symptows and way also be connected with chortnese of breath moported by Boll1ster et al. (1968).

Vartous changes of the eye are reported to take place. Two researchars (Allentuck ot al., 1942; Gesk111, 1945) support the popular bellef that the drug causes dilation of pup1la; however, no recent study supports a change in pup1l sise. The pup1l dilation wyth may be an 
artifact of the practice of swoking ancihuma in a darkened roon

(Grinopoon, 1969). The hewry epellds reported by two recearchers

(Charen et a1. 1946; Halpern, 1944) any be a reault of droweinese or of mascular waknese (Sengetake, pereonal comminication). The final ere sympton, Injection (radnese) of the conjunctives, is a coman sympton raported by many reecarchere (See Table III). Hollieter at al. (1968) report that the conjunctivae becan injected after the firat hour or two and perelated throughout the course of the drug action. This symtom appeared at all dosage levele to som degree.

A final, eomewhat "oubjective" phyelologieal amptom te that of headache. Alhough not eavere, this is an often reported oymton, especially early in the intordention (8ee Table III).

Ane (1958) reporte com electroencephlographle changes, though 11 readinge resained within normal lintte.

The finnl category of phyelological eyuptons to be coneldered are those dealing wth changes in pule rate and blood preseure. An incrense In the rate at which the heart is beating is the woet often reported phyalologteal syaptom (See rable III), and often there is conelderable enchycardia. Gaki11 (1945) is the only reeearcher to report a decrease In hart rate, which reportedly occurs when the patient "loses consclousnese." From Kajor Gakill's deseription, it is wore 11kely that his oubject went to eleep. Ame (1958) and Grinspoon (1969) tentetively roport a rise in blood preasure. Howerer, Holl1eter ot al. (1968) in a well controlled study demonotrated a decrease in blood presours. Both increase and 
decrease are well within normal IInfte and ang be artifacts of the expertantal eiturtion.

\section{Perfornence Tests - Humnn}

Of final interat in mman etudies before revianing work done with andrale are those etudies which give some wesure of performance under the Influence of the drug.

Pravlously montionad is Aldrich's (1944) atudy to tast the effecto of Earthuana on mustcal ability, In which be formd cone decrease in ab111ty as masured by the Sanhore Test (1938). Bonever, Morrow (1944) raports no impairment in hearing acuity or malcal ability. Morrow aleo reports no change in the ability to judge short pertode of tan or ohort distances though the drug did affect renction tive comiex etinull. Horence Bnlpern (1944) used intelligence teote in exmining the effects of marthuann. Performance on nubber concepte tended to decline, but ceores on teste of momory or verbal factlity alther remained unchanged or 1mproved. Allentuck et al. (1942) also noted thet scores on achlevement teste ware only "olightly lowered, if at all." Hollieter et al. (1968) noted a sloufing of performnce on a Nuber Fac1lity Test, though the sceuracy remalned high in his group of subjects who were "wall educated." B. also noted in Impatrment in eccuracy in the Maxbllity of clasure Test. Well et al. (1968) ueed a number of performance teete in a vell controlled etudy uolng both natve and expertenced subjects, placeboe and Earthuma. Bxpertenced ueers know that thoy ware enoking anthuna. 
Attempte were made to control dosage by Instructing the subjects in a etundard technique to uee in sooking thatr two efgarettes. Thay found no change in elther the naive or experienced group in a Continuous Performance Test in wich the oubject wes to reopond to a target letter whenevar it was flabhed on a screen. Rerformance on a diglt aybol teat we Imalred in the nafve user, but not with experienced users eren at the higheet dosege 1evels. The ane eort of date was obtalned for porautt rotor performnnce. In thle cees, however, axpertenced subjecte ectually Improved, perhape from pracelce effect. Rerhape the nost Important differences are those between the experienced and naive eubjects. All of the expertenced ueere felt "high" but howed little Irpatreant, wh1le only one nalve subject felt "high" and yet all natve subjects shomad cone degree of Implrment. This Indicates that axperiencad usere are able to compensate for drug effecte, to scas degree. These results also Iend aupport to the hypotheals that new users must "learu" to feel. "htgh" by learuing to recogatse the eyuptone of "Intordention."

\section{Anterel studies}

As can be seen in Table IV, relatively few otudieg have usad enimele es subjects, In part because of difficulties in adiniatering controlled doses of the drug. Mre studles used a exthuane extract (Carilnt \& Car11n1, 1965; Carlint \& Kramer, 1965; Poraaud at al., 1967; Salustiano at a1., 1966; Sentos et a1., 1966), f1ve uead tetrahydrocennabinol (TrC) (Daglrmanj1m at a1., 1962; Carriote at a1., 1967; Lapa et al., 1968; 
Schackel et al., 1968), one used both an extract and IBC (Irwin, upubliohed), one ueed hashtoh woke extrect (V1elra et al, 1967), and cae Brestlien researcher und "combustion producte of ant huana" (VIetra et a1., 1961). Bowever, only an abstrect of this study we avallable.

\section{TABLE IV}

BEHAVIORAL AND PHTSIOLOCICAL CHANGES - ANTMAL

\begin{tabular}{|c|c|c|c|c|c|c|c|}
\hline \multirow[t]{2}{*}{ Change } & \multicolumn{7}{|c|}{ Study in which it was reported } \\
\hline & Mea & Monker & Cat & Rat & Dose & Rabbit & "Antene" \\
\hline Aenota & 25,51 & 25 & 25 & & 41 & & \\
\hline Irrenare & 31 & 42 & & & & & 21 \\
\hline Abdoninal contractione & $\mathbf{s o}$ & & & & & & \\
\hline "Poetural arrent" & 25 & 25,42 & 25 & & & & \\
\hline Motor activity-increace & & & & 10 & & & \\
\hline Motor activity-decrease & 25,41 & & & & & & \\
\hline Motor activity-no change & 40,41 & & & & & & \\
\hline "Exelteation" & 50.51 & & & 25 & & & \\
\hline Peralynie, depreention & 50 & 42 & & & & & \\
\hline Agreselon-1ncrease & 50 & & & 10 & & & \\
\hline Agreaston-decrene & $\begin{array}{l}19,40 \\
41\end{array}$ & & & & & & \\
\hline Voenllation Inerease & & & & 10 & & & \\
\hline Corneel reflex decrease & & & & & & $\begin{array}{l}40,41 \\
48\end{array}$ & \\
\hline
\end{tabular}


TABLE IV - Continued

BEHAVIORAL ADD PHISIOLOGICAL CHANGES - ANTML

\begin{tabular}{|c|c|c|c|c|c|c|c|}
\hline \multirow[t]{2}{*}{ Change } & \multicolumn{7}{|c|}{ Study in wich it was reported } \\
\hline & Mice & Monker & Cat & Rat & Dors & Rabb1t & "Ani=10" \\
\hline Narrowing palebral flesure & 50 & 50 & & 50 & & & \\
\hline Hunger Increase & & & & 10 & & & \\
\hline Hunger decrease & & 42 & & 10 & & & \\
\hline Voutting, diarrhea & & & & & & & 21 \\
\hline Sexual "exaltation" & 51 & & & & & & \\
\hline Increased DNM in brain & & & & 9 & & & \\
\hline Blood pressure decrease & 14 & & 14 & & & & \\
\hline Respiration decrease & 14 & 25 & 14 & & & & \\
\hline Stunting of fetus & 36 & & & & & & \\
\hline
\end{tabular}

IIndleates number of study In reference section. 
An Important group of effects deal with auscular contractions and motor activity. Ataxia has been reported in doge (Santos at a1., 1966), alce, monkeys and cate (Inin, umpublished manuscript). Grinopoon (1968) reports that antenis exhiblt "tremors" at hgh doenge levels, and this is supported by evidence from a study with monkeys recently completed by Scheckel et al. (1968). Abdominal contractions, olnilar to parturition, wore observed in wice (V1eira, 1967). Rerhaps the wost dranutic eymptos 19 the tendency of an enimal to hold a particular poeltion for a long pertod of tive. Irwin (umpublished nanuscript) calls this "postural arrest." He obeerved this in atce and squirrel monkeys, scheckel et al. (1968) describe a ofillar oymtem in his etudy, aleo wth wonkeys. Posably minted to postural arrest is a decrease in epontaneou motor ectivity also reported by Irwin (umpublished nanuecript), though alight. santos et al. (1966) report decreases in eponteneous notor ectivity in wice only at very high dosage levele (lethal to some alce). At lower 1evelo he found no change in motor activty, resulte oupported by a alnslar wouse etudy Hoahino et al. (1966). Carlind at al. (1965) working with rate reporte an incrase in wotor activity; however, they related this to Increased axcitability, as oupported by V1eira (1967), whos mice wre particularly ousceptable to anditory otimulation. Scheckel at al. (1968) reports thet, with monkeys, a "stiwulant phase" In which the entmale appear to be halluctnating is followed by a "depreseton" in which the monkey crouchea wotionlesa for periods up to a wek, sometines dying of starvation. Vielre (1967) reporte a almilar 
depreselon with wice, which often led to paralyals and dath at high dosed ( $350 \mathrm{mg} / \mathrm{kg}$ of haohtoh sake extract). V1e1ra (unpublished mnuer(pt) also reporte that marihuena 1nereaee "exeftability." In the state of chronic intoxication, the animals lose thair natural chara and Avec1ty, teking on a norbid sopect. . .eaxul exaltation and asgreselvenees were obeerved." It should be noted that these dosage 1evele, if accurate, are ridiculously high.

Changes in aggreseion have been a "folklore" oyptom of inarihuana for some tine, Carlint and Tramer (1965) report Increased agsression as a -1da observation in a learaing etudy with rate. A number of wellcontrolled etudies wth wlce raport decreases in agsreselve behrior, even in etraine of alee bred for fighting bahaviore (Garriott at al., 1967; Salustian at al., 1966; Santos at al., 1966).

Carlint and Kramer (1966) report Inereased vocallation whenevar their rate wre touched. This way be fent resction, as reported in the human studies discuesed previously.

A narroulng of the palebral flesure has been noted in cowe intuals, particularly utce (V1elra, 1967), and perhape corresponde to "hasy cyellde" reported by human subjects (See Tabla III).

The drug appeare to have a complex effect on hunger related to the doeage Leval. Carlinl and Kraner (1965) report Increased hunger as a result of Infection of marthusna extract. Hovever, if the dosage Ievel is high, this effect lasts for a ohort twe and is rapleced by a distateraet In food, Scheckel et al. (1968) report that wome woakeye (at wary high 
dosage levels) etarved to death in thetr post-drug depression. Grinspoon (1969) reporte diarrhas and roatting in wowe animls at very high dosage 1eve1s.

Daglrmanflan et al. (1962) report decreases in blood preseure and resplration in both ulce and cate at high dosage levelo of tetrahydrocannablnol.

Only two studles dealt wth the effects of merthuma on learning. In one, V1eira et al. (1967) demonstrate spectfic ouppraseion of the Conditioned Aroldance Reeponea, ualng a Varner-type shuttle-box. The dosage levels hare were extremely high, $250 \mathrm{mg} / \mathrm{kg}$ hahtoh smoke extract, lethal to wany atce.

The second etudy is of particular interest. Carlint and krawar (1965) wed a Lahley III alley mase to teat the effecta of narthuana extract on running tine and number of errors. They found that andmale Injected wth the extract before runing, group II, performad afgifleantly better (p 0.05) than the control group. However, rate recelving narthuane Injection after runing, group III, showed wore errors than evan the controls, who were injected wth a control solution after the trial. There are a nuber of veaknesses in this etudy. From the design, there was no control group recelving Injections before trialo; therefore, it is poselble that an injection of the control solution before the trials could have had an effect sinilar to the warthuana extract. The otudy appears to have been designed in this nanner in an attempt to deternine effecte of marthume on nowory coneolidation. It appeare from the data 
that the group distributions wre very okewed (1.e., a wan of 187.9

seconds, runalng time, with a stendard deviation of 236). However, easuning

for a monent that Injections of marihuma extract do improve mae performance, we can hypothesize a nuber of explanations. Flret, we might hypothesize that the improvement 1 a a reoult of Increased bunger. Increased tunger has been shown to Improve ruming spead (KIntech, 1962; Reynolds et al., 1960; zaretaky ot al., 1966). The proposel that arithuna might increase hunger is In concordance with previously mentloned reporte of human subjects (Allentuck, 1955; Grinopoon, 1969; Boll1oter et al., 1968; S1lar et al., 1933; Velge at al., 1962; Well et al., 1968). However, Carlinl and Rraser (1965) are the only researchere to report Increased huger In enimals. At doeage levele highar them $30 \mathrm{mg}$ of marthuana extract (a high dose), eating behavior wes suppreseed. Athough these revarchers go into a detalled description of why injectione after the triale do not enhence learning, they offer no hypotheele as to why thay Aght enbunce learning when injected prior to the triala.

A aecond hypothesis aght relate to either a change in perceptual ablifties or en enhencement in learning proceseas. Hunn studies, as previously clted, give some support to the iden of chenges in perception. However, if any real concluatong are to be dram from aninal etudies, it 1. flret naceseary to deternine the effects of the drug on eating bahaviox, elnce food 18 , by far, the woet common relaforcer.

It 1s the purpose of this study to deternine the effects of anithuna, at different dosage levels and deprivation atates, on eating behavior in rate. 


\section{CHAPTER II}

METHOD

Marthuana extract dist1late, MED, obtalned from the National Inat1tute of Mental Health, Chevy Chase, Maryland, was used in an affort to control the amount of tetrahydrocannabinol, $\Delta^{9}$ THC. The dist11late also contains $\triangle^{8}$ IHC and other, possibly active, chemicals. The dosage levels were chosen in consideration of a number of factors. A 300 mg Mexican marihuana cigarette has been calculated to contain 1.57 ThC from Which about 507 is absorbed by the amoker (Bfron, 1967). Iobell (et al, 1967) reports that marihuma is about thres t1mes as potent when swoked as when taken orally. Accordingly, comparable doses per $70 \mathrm{~kg}$ man per cigarette can be expected to be about $0.052 \mathrm{mg} / \mathrm{kg}$ moking or $0.155 \mathrm{mg} / \mathrm{kg}_{\mathrm{g}}$ orally. Carlint and Rramer (1965) used a dosage level of $10 \mathrm{mg} / \mathrm{kg}$ marthuana extract, THC content unknown. Therefore, dosage levelo vere chosen such that the lowest, $0.15 \mathrm{mg} / \mathrm{kg}$ corresponds to the amount which causes perceptual changes in man. The mediun dosage level is ten times greater and correaponda to a "heavy" dose in man and the high dosage Ievel 1s ten times greater than that. (Iobell et al, 1967)

The drug solutions were prepared in the following manner. The merthuane extract dist11late, contalning $17.17 \Delta^{9}$ IHC, wae euspended in a normal saline solution with $4 Z$ Tween-80 to ald suapension (Carlini and Krawer, 1965). The drug was adminletered orally, wth on Intraesophogeal 
tube and en hypodernic ortage.

Subjects were 20 mile and 20 fenile spragua-Darley albino rats. They wre mintalned In their how cages on ad-11b food and water during the course of the experiment. Bach of the animals wa eseigned to one of five groups, so that ench group contalned four miles and four fomales. The elrat group (THC) was given warlhuma extract dist1liate at the level of $15 \mathrm{mg} / \mathrm{kg}$ body valght; the eecond group (TIC), $1.5 \mathrm{mg} / \mathrm{kg}$; the third group (THC), $0.15 \mathrm{mg} / \mathrm{kg}$. Tha fourth group, INN, recelved caly the carrier solution and the fifth group, MOCx, underwent the ease admintetrative procedure but wth no actual Ingestion of any aubatance. Bach animal was tasted once under each of the following four coaditions; lood and water present at all thes (ad-11b); food wthdram 12 houre prior to Ingestion of drug, water present at all times (12 hour); lood withdrain 24 hours prior to Ingestion of drug, water present at all tiwe (24 hour); food wthdram 48 houre prior to Ingestion of drug, water present at all tines (48 houre). Bech entenl was tested under all Lour deprivation conditions wth approximntely one weck rest after ench teat. The order of presentation of the four deprivation schedules was aselgnad according to a balmeed Iatin square destgn.

The study was divided Into two parts, esch of four weeks' duration. In the firat part (Bxperiment I), after adninietration of the drug, the animals ware imediately placed into a cage wth a known anount of food present. The food was walghed after three hours and again after 24 to datermine the sount of food eaten during each of these periode. 
Experdment II repeated all procedures unchanged except that the enimals were not given food unt1l k-hour after the drug was adninistered. Th1s was to allow for drug offecte to appear before eating began. 


\section{CEAPTER III}

RESULTS

Date for weles and females were examinod separately uning Cochran and Cox'e (1957) design to deternine residunl effects. Finding none to be algntflent, the data were collapsed over order ylelding four animals per cell for Winer's (1962) pty factorlal design for repeated measures. The resulte of that enalyele are presented in Table $v$.

\section{TABLE V}

F VALUES FOR AHLTBIS OF VARTARCB

Part 1

No Latancy

\begin{tabular}{|c|c|c|}
\hline \multirow{2}{*}{$\frac{\operatorname{sex}}{\operatorname{Min}}$} & \multicolumn{2}{|c|}{ E Velues } \\
\hline & Dosure Leve1 & Deprivation Level \\
\hline $0-3 \mathrm{hr}$ & 0.30 & $26.76 \mathrm{mth}$ \\
\hline 3.24 & 18.49 mith & 1.34 \\
\hline $0-24$ & 23.58 th & 17.51 th \\
\hline \multicolumn{3}{|l|}{ Iranle } \\
\hline $0.3 \mathrm{hr}$ & $4.25 *$ & $20.10^{\text {tht }}$ \\
\hline $3-24$ & $4.92 k n$ & 1.73 \\
\hline $0-24$ & 9.67 t* & $17.31 *$ \\
\hline
\end{tabular}


TABLE V - Continued

Part 2

b-Bour Letency

\begin{tabular}{|c|c|c|}
\hline $\operatorname{sex}$ & & \\
\hline Male & Dosage Leve1 & Deprivation Leve1 \\
\hline$\frac{1}{2}-3 \mathrm{hr}$ & $3.14^{*}$ & $37.08 * k$ \\
\hline $3-24$ & $10.34 * *$ & 0.51 \\
\hline$\frac{1}{2}-24$ & $24.39 * *$ & 38.18 th \\
\hline \multicolumn{3}{|l|}{ Female } \\
\hline$\frac{1}{2}-3 \mathrm{hx}$ & $9.70^{\text {t* }}$ & $22.04 * k$ \\
\hline $3-24$ & 1.63 & $3.25 *$ \\
\hline $12-24$ & $6.32 * *$ & 18.89 \# \\
\hline
\end{tabular}

\footnotetext{
$\star=p<0.05$
}

th $-p<0.01$

In Inftial exeaination of that table, it can be observed that deprivation level is a ofguffeant factor in deternining the wount of food eaten. In addition, level of deprivation appears to be wost Important during the flret three houre of food presentation. A IewmenKeuls operation (WIner, 1962) was performed to deternine the direction of effects. The reoults are presented in Table VI. 
TABLE VI

NEWLAN-KBULS RESULTS

Part 1

No Latency

\begin{tabular}{|c|c|c|c|c|c|c|c|c|c|}
\hline \multirow{3}{*}{$\frac{\frac{8 e x}{\text { Mele }}}{0-3 \mathrm{hr}}$} & \multicolumn{9}{|c|}{ Ordered Mene } \\
\hline & \multicolumn{5}{|c|}{ Dosege Leval } & \multicolumn{4}{|c|}{ Deprivation Level } \\
\hline & \multicolumn{4}{|c|}{ Fot significent } & \multirow[b]{2}{*}{ INAN } & Ad & 12 & 48 & \multirow[t]{2}{*}{24} \\
\hline $3-24$ & $\operatorname{THC}_{1}$ & $\mathrm{IHC}_{2}$ & MOCK & $\mathbf{I H C}_{3}$ & & \multicolumn{3}{|c|}{ not elgnificant } & \\
\hline $0-24$ & $\mathrm{IHC}_{1}$ & $\mathbf{T H C}_{2}$ & MOCK & $\mathrm{IAC}_{3}$ & TN & $\mathbf{M}$ & 12 & 48 & 24 \\
\hline \multicolumn{10}{|l|}{ Fenale } \\
\hline $0-3$ & $\mathrm{THC}_{1}$ & $\mathrm{THC}_{2}$ & $\mathrm{THC}_{3}$ & TWN & $\mathrm{MDCK}$ & Ad & 12 & 48 & 24 \\
\hline $3-24$ & $\mathrm{IHC}_{1}$ & $\mathbf{H A C}_{2}$ & MOCX & 2xin & $\mathrm{IHC}_{3}$ & \multicolumn{4}{|c|}{ I not olgntflcant } \\
\hline $0-24$ & $\mathrm{THC}_{2}$ & $\mathrm{TRC}_{2}$ & MOCK & $\mathbf{r a c}_{3}$ & InI & Ad & 12 & 48 & 24 \\
\hline
\end{tabular}

Part 2

L Hour Latency

\begin{tabular}{|c|c|c|c|c|c|c|c|c|c|}
\hline \multirow{3}{*}{$\begin{array}{l}\frac{\mathrm{Male}}{\mathrm{L}-3 \mathrm{hr}} \\
3-24\end{array}$} & \multicolumn{5}{|c|}{ Dosage Leve 1} & \multicolumn{4}{|c|}{ Deprivation Ievel } \\
\hline & \multirow{2}{*}{$\begin{array}{l}\mathrm{mAC}_{1} \\
\mathrm{me}_{1}\end{array}$} & \multirow{2}{*}{$\begin{array}{l}\mathrm{THC}_{2} \\
\mathrm{MHC}_{2}\end{array}$} & \multirow{2}{*}{$\begin{array}{l}\mathrm{IRC}_{3} \\
\mathrm{IHC}_{3}\end{array}$} & \multirow{2}{*}{$\begin{array}{l}\text { Mock } \\
\text { mock }\end{array}$} & \multirow{2}{*}{$\begin{array}{l}\mathrm{TWN} \\
\mathrm{TWN}\end{array}$} & \multirow{2}{*}{$\begin{array}{l}\text { Ad } \\
\text { I no }\end{array}$} & 12 & 48 & \multirow[t]{2}{*}{24} \\
\hline & & & & & & & 18 & Eles & \\
\hline$x=24$ & $\operatorname{IHC}_{1}$ & $\mathrm{HC}_{2}$ & $\mathrm{THC}_{3}$ & $M O C K$ & $\operatorname{Tn}$ & $\Delta d$ & 48 & 12 & 24 \\
\hline \multicolumn{10}{|l|}{ Penale } \\
\hline$x-3$ & $\mathrm{HAC}_{1}$ & $\mathrm{IIC}_{2}$ & $\mathrm{xHC}_{3}$ & $\operatorname{Twn}$ & $\mathrm{MOCK}$ & $\mathbf{A d}$ & 48 & 12 & 24 \\
\hline $3-24$ & & F not & Ignes & Leant & & $\mathbf{A d}$ & 48 & 24 & 12 \\
\hline$x-24$ & $\mathrm{HHC}_{1}$ & $\mathrm{THC}_{2}$ & $\operatorname{Tn} x$ & $\mathrm{IIC}_{3}$ & $200 \mathrm{CK}$ & $\mathbf{A d}$ & 48 & 12 & 24 \\
\hline
\end{tabular}

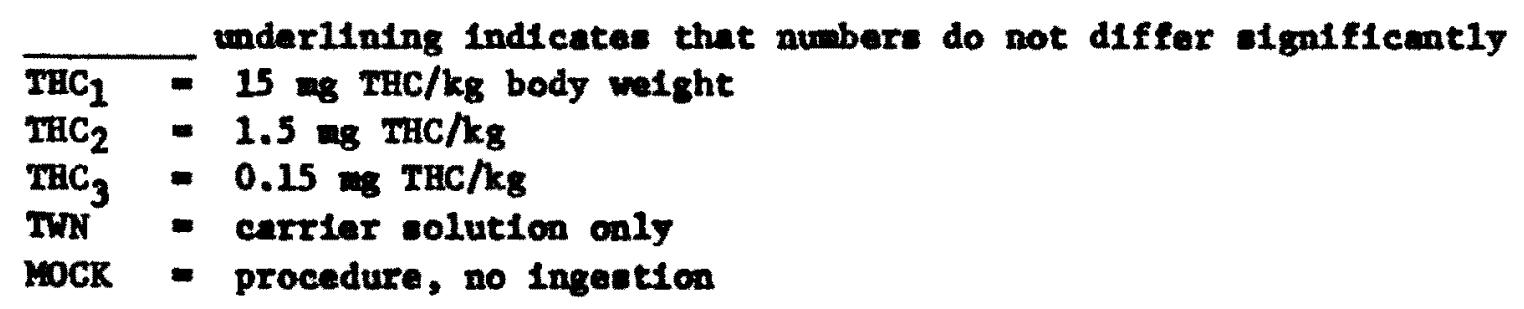


As wight be expected, the ad-11b group consiatent1y ate the least mount of food. Similarly, the group deprived for 24 hours ate the wat, wh the 12 and 48 hour groups falling between.

of primary Interest in thls study, dosage level was also a significant factor for both male and femele mimals. Results of the statistical analysis are presented in Table V. In all cases, dosage level was a of gnificant factor $(p<0.01)$ in determining the amount of food eaten at the 24-hour we1ghing. However, it can be observed that females vere effected somewhat differentiy than males. In Bxperiment I, with food presentation tmediately following drug administration, fewales showed drug effects during the f1rst three hours while males did not. Likewise, In Experiment II, with a 3 -hour latency batween drug administration and food presentation, whtle both males and females showed drug effects during the first 3 hours of the experimental perfod, only the males demonstrated any effects in the 3-24 hour perfod.

A Newman-Reuls operation (WIner, 1962) vas performad to deternine the diraction of effects and the results are precented in Table VI. In all cases, if $\underline{I}$ is olgnificant, dosage level of Marthume Extract Distillate 18 inversely related to the amount of food eaten. The highest doage level, $15 \mathrm{mg} / \mathrm{kg}$, always resulted in the least anount eaten, the eecond dosage level group, $1.5 \mathrm{mg} / \mathrm{kg}$, eat1ng somowhat more. No defint te trend could be determined for the lowest dosage level or the two controls. In general, similar amounts of food were eaten by these three groups.

No agnificant Interaction was observed between dosage and deprivation level. 


\section{Cavual Obeervations}

A number of additional observations may be of Interest though they vere casurl. The behavior of the an1male at the higheat dosage level was quite obviously effected by the drug. The antmals would spend long periods of time motionless in their cages, of ten in unusunl positions, 1.e., head and one leg ralsed, standing on hind legs, etc. This is statlar to Irwin's (unpublished manuscript) description of "posturel arrest." Any sharp notse or movement would cause the enimal to change posttion. Increased rocallzation was also noted. Squealing could be ellclted by noving an object into the animal's lateral vision. As the study progressed, some animals, at the highest dosage, would exh1bit Increased vocallzation, long after other drug effects had ceased.

If the animal were ploked up, urination and defecation ueurlly accompanied the squealing. If the animal were placed on a table or floor, 1t would spread 1ts legs wide as if for better balance, and efther rafuse to wove or would walk in circles with one foot stationary. If the animal were held suspended, it would hold onto any object, pencils or flngers, which touched $1 \mathrm{ts}$ feet. When placed with an estrus female, anle at the highest dosage level showed no Interest, h1s only response being to squeal if touched. A number of times one male stood motionless under hts water bottle whlle the ent1re contents dripped over him. Antmals at the medium dosage lovels rarely exhlbited any of the above behav1ors. No unusual behavlor was observed in elther the lowest dosage group or the two control groups. 


\section{DIscussion}

statemente concerning direce affecte as exenined by this design,

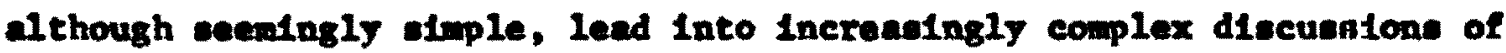
the effecte of the various Independent variables. Two Initial observations appear to be; A) that the data Indicate that the level of food deprivation hes a direct effect on the abount of food eaten, and b) that Mrrihuna Bxtract Detillate he a direct affect upon the anount of food eaten, that effect generally belng in inverae relation betwean anount eaten and dosage level of the drug.

The effects of food deprivation wre in the direction that would be expected from a number of atudies (Dufort at al., 1962; Reyolds at al., 1960). That 1s, animals tend to ent wore wth Increasing periode of deprivetion to a point, after which conouption decreases. Thue, as the animalo In this atudy were deprived for increatng pertode of the up to and Including 24 hours, they tendad to eat wore after which (48 hours of deprivation) they tonded to eat lese. This I1nding, though not was, pointe to a consideration that wut be ade in any experiventation which ut1linea deprivation in an effort to Incrence motivation.

of wore Interant to this Inveatigntor wre affecte ralated to doage lovel. At flret glance, it appeare that ovidence indicating dacreased eating behavior is in direct oppoattion to other atudies relying 
on humen reporte (Ames, 1958; Grinopoon, 1968; Hollister et a1, 1968). However, both Ames and Grinapoon relate "Increseed hunger" to "taste enhancement." Thus, a peraon eats wore because the food tastas better rather than because of Increased hunger. "Taste enhancewent," if present In rats, an have 11ttle effect of the taste of lab chow, the food eaten by the experimental minals. If some other mre "denlrable" food were offered, this effect wght be observed.

Carlint and Kramer (1965) reported "Incressed appetite." The enimals reportedly axhibited th1. 1ncreaeed appetite for about " 3 to 3 m1nutes". However, as time elapsed, the animals showed "algne of depreselon and did not look for tood any nore (pp. 177)." The data in the present study may be Interpreted to support Carlind and Kraner's observation. Since the animals In Bxperiment I were presented food with no delay, thay may have exhibited an Inftial burst of eating behavior followed by a depression of eating. However, the design of the etudy did not allow for direct observation of this effect elnce the food was welghed only at 3 and 24 hour perfods. The observation that the animale In Bxperiment II ate lese food than those in Bxperiment I when compared to their reapective controls offers Indirect support to en "Initinl Increased hunger" hypothes1s. Thus, by delaylng presentetion of food in Experiment II unt1l after the "Initial appet1te" would have occurred, the total mount of food eaten in the 3-hour perfod is decreased conelderably. Another Interpretation of these sam data 1s poselble. Asauning for 
a woment that no Inttial "Incresed appetite" occurs as a result of the drug Ingestion, we st11 expect animals to eat when presented with food, particularly those which had been deprived for perlods up to 48 hours.

In Experiment I (no delay) the animals would have been able to do a good deal of eating before drug effects appeared. However, In Experiment II (K hour delay) the effects of the drus have appeared before food 18 presented, resulting in less being eaten. Further research is necessary to detexwine the exact course of drug effects.

The actual depression of eating behavior may be a function of decreased hunger, or a function of a general decrease in motor activity.

Also of Interest is the observation that females appear to be effected somewhat differently by the drug than males. Again, wore than one interpretation is possible. Because the fenales were approximately 150 grams 11ghter than the males, and because dosage was determined in mg/kg, It is possible that effect of dosage level is not deacribed by a Iinear model. In other words, a $10 \mathrm{mg}$ dose to a $200 \mathrm{mg}$ antmal may not be comparable to a $20 \mathrm{mg}$ dose to a $400 \mathrm{mg}$ antmal. It $1 \mathrm{~s}$ also possible that females were elther wore susceptible to drug effects, or that they reacted wre quickly at those dosage levels. Thts same phenomenon has been observed with other drugs (Irwdn, personal commulcation). In the first portion of the study when food was presented directly after drug administration, dosage level was agnificant only for the females during the first 3-hour period. In the second portion of the study, when a 
latency pertod of $y$ hour occurred between drug edatinistration and food presentation, Ienales again showed a higher level of eignificance $(p<0.01)$ than did the males $(p<0.05)$. The observation that females ahowed no drug effect in the 3-24 hour period lends some support to the hypothesis that females way react and recover wore quidkly from the drug effecte. Mnally, the casual observations give some indications that the effects of the drug are not confined to a general supprestion of movement. "Enhencement" of pereeptual experience could be a posetble explanation for the increased vocalization, urlnation and defecation cccurring when an animal was disturbed. Of further interest is the observation that eome behavioral chngee apeared to outlast the "direct effecte" of the drug. Whether this way be due to "long term effecto" or to learnad responses is beyond the ecope of this study. However, fertile ground for further research is ouggested. 


\section{CHAPTER V}

\section{CONCLUSIONS}

Th1s study has shown that Marihuana Extract Distillate depresses eating behavior in rats at medium and high dosage levels. This may be due to decreased appet1te, or by a general decrease in physical activity. There 1 also some indication that females way be effected by the drug somewhat differently than males. Further research is necessary to determine the basis of that difference.

Whatever the explanations for these effects, they lead to considerations which must be made in any research ut1lizing marthuana as an Independent variable and food or food deprivation as a motivating factor. 
1. Abelson, P. H. LSD and Marthuana, Sclence, 1968, 159 (3820), 3.

2. Adams, R. Marthuena. Sclence, 1940,92 (2380), 115-119.

3. Aldrich, C. K. The effect of a snthetic Maribuana-like compound on musical talent as measured by the Seashore test. Public Health Reports, $1944,59,431-433$.

4. Allen, J. R. Fllght from rlolence: Hipples and the green rebellion. American Journal of Psychlatry, 1968, 125 (3), 364-370.

5. Allentuck, S. \& Bownan, K. M. The psychiatric aspects of Marthuana Intoxication, Amarican Journal of Poychtatry, 1942, 99 (2), 248-251.

6. Allentuck, S. In The Marthuana problem in the clty of New York, by the Mayor's Comittee on Marihuana, Lencaster, Pennaylvania; The Jeques Catte Press, 1944.

7. American Medical Association. Dapendence on Cannabis (Marthuna), Journal of the American Modical Assoctation, 1967, 201 (6), 368-371.

8. Aas, F. A clinical and netabolic study of acute intoxication with Cannabls gativa and its role in the model paychosis, Journal of Mental Sclence, 1958, 104, 972-999.

9. Carlini, G. R. S. Carlinl, E. A. Effects of Strychnine and Cannabis sativa (Marthuana) on the nucleic acld content in the braln of the rat, Madical Pharmacology Experiments, 1965, 12, 21-26.

10. Carlint, E. A. Rramer, C. Effects of Connab1s mativa (Marthuana) on maze performance of the rat, Poychopharancologia, 1965, 7, 175-181.

11. Charen, S. \& Perelman, L. Personellty studies of Marthuana addict», Amertcan Journal of Paychtatry, 1946, $102(5), 674-681$.

12. Clark, L. D. Bxpertmental studles of Marthuana, Amertcan Journel of Psychiatry, 1968, 125(3), 379-384.

13. Cochran, W. G. \& Cox, G. M. Experimental Dastgna, (2nd ed.) Now York: wiley, 1957. 
14. Dagirmanjtan, R. Boyd, B. S. Som pharmacological effecte of two tetrabydrocannabinols, Journal of Pharmeological and Experinentel Therepy, 1962, 135(1), 25-33.

15. Dufort, R. H. Wright, J. H. Food Intake as a function of duration of food deprivation. Journal of Peychologr, 1962, 53, 465-468.

16. Eddy, H. B., Halbach, H., Iobe11, H. \& Seevere, M. H. Drug dependence: Its igaificance and characterietice, Bulletin of the Norld Bealth Organication, 1965, 32, 721-733.

17. Bfron, D. B. Cannabls (Marthuma) research Ioported to the Comittee on Problem of Drug Dependence (Unpublished).

18. Fabing, H. D. The dieenelons of Beurolog, Deurology, 1955, 5(9), 603-611.

19. Garriott, J. C., King, L. J., Forney, R. B. Hughes, F. W. Bffects of aone tetrahydrocannabinols on haxobarbital eleeplng time and aphetaine induced hyperectivity in atce, Life Selences, $1967,6,2119-2128$.

20. Gaok111, H. S. Marthuana, in Intoxtcent, Amertean Journal of Perchietry, 1945, 102(2), 202-204.

21. Grinepoon, L. Marthuana, Selentifle Avericen, 1969, 221(6), 17-25.

22. Halpern, F. In The Marthuane problem in the c1ty of Ilew York by the Moyor' Comittee on Marthuane, Lenceater, Renneylvania The Jequee Catte Prees, 1944.

23. Hollister, L. E., Rlchards, R. K., Gilleeple, H. K. Comparicon of tetrahydrocannabinol and synhexy 1 in man, Clintcal Pharascolosy and Therapeut1ce, 1968, 9(6), 783-791.

24. Imper1, L. L., Rleber, H. D. Davie, J. S. Uee of hallucinogente druge on campua, Journal of the Americen Hedical Aseocietion, $1968,204(12), 1021-1024$.

25. Iruin, s. Effect of Marthuane and d, 1- $\Delta^{6}$ tetrahydrocannabinol on the mouse, cat and equirrel monkey, Unpublished nnuscript, Oniveratty of Oregon Kadical school.

26. Iebel1, H., Gordetaky, G. W., Jasingk1, D., Clauseen, U., Spulak, F. V. - Korte, F. Bffects of $\Delta^{9}$ trane-tetrahydrocannabinol in un, Peychopherencolog1e, 1967, 11, 184-188. 
27. Keeler, M. B. Adverse reaction to Marthuane, Amertean Journal of Peych1atry, 1967, 124(5), 674-677.

28. Reeler, M. H., Relfler, C. B. ILptzin, M. B. Spontaneous recurrence of Marthuena effect, Apartcan Journal of Peychiatry, $1968,125(3), 384-386$.

29. Keeler, M. H. Motivation of marihuma use: a correlate of adverse reaction, Amertcan Journal of Peych1atry, 1968, 125(3), 386-390.

30. Kintsch, w. Runway performance as a function of drive strength and magnitude of revard, Journal of Comparative and Phyalologtcal Paychology, 1962, 9(6), 783-791.

31. Lapa, A. J., Smpa10, C. A. M., TImo-Iaria, C. Valle, J. R. Blocking action upon transuisetion in the trigeninal syaten of the cat, Journal of Pharmacy and Pharmacology, 1968, 20, 373-376.

32. Lorner, M. Marihuana: Tetrahydrocannabinol and related compounds, Science, 1963, 40(3563), 175.

33. McGlothlin, W. H. \& West, L. J. The marthuana problew: an overview, American Journal of Peychletry, 1968, 125(3), 370-378.

34. Morrow, R. S. In The mar1huana problem in the c1ty of New York, by the Mayor's Comnittee on Marthuana, Lencaster, Pennaylvania: The Jacques Catte Press, 1944.

35. Nesbitt, M. Paychosis due to exogenous toxdne-Karihuana, Illinols Medical Journal, 1939, 278-281.

36. Persaud, T. V. N. Ellington, A. C. Cannab1s in early pregnancy, Incet, $1967,2,1306$.

37. de P1nho, R., P1nto, L. P., Sempalo, A., Sentos, D., Kruschewaky, C., Azevedo, V., Nazareth de Andrade, A., \& S11va, N. Contribulcao a meea redonda eobre "Problemae eocio-peicologicos do maconhiemo" No. 5 congresso de cociedade de neurologia, palquiatria e higiene mental do Brastl, (Soctopsychological probless of cannabism.) Neurobiolog1a, 1962, 25(3-4), 9-19 (Abst1act).

38. Reynolds, W. F. \& Pavlik, W. B. Running speed as a function of deprivation period and reward magnitude, Journal of Comparative and Physiological Paychology, 1960, 53(6), 615-618.

39. Rodgers, T. C. Marthuna and aggresalve crim, Merricen Journal of Peychiatry, 1946, $102(6), 825-827$. 
40. Salustiano, J., Hoshino, R. Carlini, z. A. Effects of Canab1s sativa and chlorpromaxine on mice es meacured by two wethods used for evaluation of tremquilizing agents, Yodical Pharaceology, 1966, 15, 153-162.

41. Sentos, M., Sempalo, M. R. P., Farnandes, M. S. Carlin1, B. A. Iffect: of Camnab1s sativa (Marthune) on the f1ght1ng behevior of mice, Peychopharmacolog1a, 1966, 8, 437-444.

42. Scheckel, C. L., Boff, E., Dahlen, P. Smart, T. Behartoral effects in monkeys of racenates of two biologically active mar1huana const1tuents, Sclence, 1968, 160(3835), 1467-1469.

43. Senohore, C. B. Paychology of Mug1e, How York: MeGraw H111, 1938.

44. Sengatake, C. B. Personal Comanication, Portland State Univera1ty.

45. S1ler, J. 8., Sheep, W. L., Bates, L. B., Clark, G. F., Cook, G. W. 8. Sulth, W. A. Mil1tary Surgeon, 1933, 269-280 (Abstract).

46. Sonnenre1ch, C. \& Goes, J. F. Maconha e disturblos palquicos (Marthuane and mental disturbances), Euroblolog1a, 1962, 25(3), 69-91 (Abstract).

47. Tylden, B. A case for Cannab1s?, Journal of the Britieh Medical Aseociation, 1967, 5564, 356.

48. Valle, J. R., Sousa, J. A., G Hppollto, N. Rabb1t reactivity to cannable praparatioas, pyrabexyl, and tetrahydro-cannabinol. Journel of Pharnacy and Pharnacolony, 1966, 18, 476.

49. Vaiga, E. P. PInho, A. R. Contribulcao so eatudo de cannabismo no Bras11, Neuroblolog1e, 1962, 25, 26-68 (Abstract).

50. Vielra, F. J. A., Agutar, M. B., Alencar, J. W., Deabra, A. P., Tursch, B. M. \& Leclereq, J. Effects of the organlc layer of hashish enoke extract and preliminary resulte of 1ts chemical anelye1s, Reychopharmacolog1e, 1967, 10, 361-362.

51. V1elra, T. J., \& de Olivera, M. A. Sobre os efeltos dep roductos de combustao de cannabis eative mus musculue, var. alsinus. (About the effects on combuation products of Marihuma on white atce), Onpublished manuecript. Portalexa, Braxil: Imrensa Untversti. 
52. Well, A. T., Zinberg, K. B. Melson, J. M. Clinical and peychological effects of Marihuana in man, Science, 1968, 162, 1234-1242.

53. Winer, B. J. Statistical Principles in Experimental Designs, Now York: MeGraw B111, 1962.

54. Wolff, P. O. La marihuana en 1a Ameriea Latina. (Marthuana in Latin Amer1ca), Arch. Med. Legal, B. Alres, 1948, 18, 261308 (Abatract).

55. Zaretsky, В. В. Learning and performance as a function of the shift In drive and Incentive. Journal of Comparative and Phys10log1cal Peychology, 1966, 62, 218-221. 